\title{
Public Relations in the public sector. The role of strategic communication in the italian public administration
}

\author{
ChIARA VALENTINI
}

\begin{abstract}
Purpose of the paper: The aim of this study is to examine the level of strategic management of public administrations and information and communication programs by public communication officers in Italy.

Methodology: The study is quantitative in nature. It was constructed according to the findings of the Excellence Project in Public Relations and thus applies a research instrument similar to that used in other international scholarly investigations in public relations. The population comprises civil servants working in information and communication activities for Italian public administrations.

Findings: The majority of public communication officers in the Italian public administration are not involved in the strategic management of public administrations but rather contribute to operational activities. They report directly to the senior manager of their department/unit and they use a mixed model of public relations.

Research limitations: Due to a lack of information on the exact number of public communication officers working in the Italian public administration and a too small number of respondents in one of the respondent groups, it is not possible to draw inferences or general conclusions from the findings. The study also suffers from the limits of a quantitative research approach, which provides less elaborate accounts of public communication officers ' perceptions of the strategic role of communication in the public sector.

Originality/value of paper: This study contributes to the existing knowledge on strategic public relations and public communication by offering a specific analysis of the strategic management of information and communication programs in the Italian public administration.
\end{abstract}

Key words: Italy; public administration; public communication; public relations; generic principles; Grunig's four models of public relations

Ph.D. Associate Professor of Corporate Communication and Public Relations, Aarhus University, School of Business and Social Sciences, Denmark

Email: chv@asb.dk 


\section{Introduction}

In Italy a large number of public relations practitioners work for the public sector. It is estimated that between 40,000 to 70,000 public relations professionals are employed in the Italian public administration across the 8094 local public administrations (Valentini and Muzi Falconi, 2008). Known as public communication officers, public relations practitioners in the public sector are civil servants employed by the State to take care of different communication duties. The large amount of public relations professionals working in the public sector is both a consequence of the application of Italian law no. 150/2000, which requires every local public administration to have structures, so-called URPs (Ufficio Relazioni con il Pubblico), dedicated to the provision and dissemination of information and communication, but also a recognition of the importance of communication for the public sector (Valentini, 2009; Ducci, 2007). Today, communication is considered a primary institutional duty of public administrations, given that communication is a fundamental and irreplaceable resource to guarantee effectiveness, efficiency and transparency of public administrations (Fairbanks et al., 2007; Mancini, 2006; Rolando, 1995; 1998; 2003). Communication officers play an important role because they contribute to the public understanding of the administration's policies and raise awareness of the roles of decision makers and purview of public institutions, the availability of social services, noteworthy trends, and risks to public health and safety (Édes, 2000).

While there is a certain amount of knowledge of the communication practices of the Italian public administration and the historical development of communication in the public sector (see e.g. Rolando, 1995; 1998; 2003; 2010; 2011; Mancini, 2006; Ducci, 2007), studies in public relations, whose focus is on "strategic communication processes that build mutually beneficial relationships between organizations and their publics" (PRSA, 2012), have so far addressed the status of public relations as a strategic function in public administrations to a limited degree. Internationally speaking, the body of knowledge in public relations in the public sector is also limited (Gelders and Ihlen, 2010a; Lee, 2001; 1999; Heise, 1985) and often descriptive and country-specific in nature (Luoma-aho and Peltola, 2006; Graber, 2003).

Given that public relations is a relatively new research field in Italy, that few studies on public relations and Italy exist (Invernizzi and Romenti, 2009a; 2009b; Valentini, 2009) and that the public sector in public relations scholarship is underresearched, the aim of this study is to examine whether public communication officers in Italy are involved in the strategic management of public administrations, and manage their information and communication programs strategically. This study is based on the findings of the Excellence Project (Grunig, 1992) and adopts a research instrument similar to that used in other international studies in public relations (cf. Vercic et al., 1996). A reason for choosing this research approach is the possibility to collect data that can be compared with other investigations on the strategic management of public relations across countries. 


\section{Strategic Management and Public Relations}

Strategic communication broadly refers to communication activities that, from development to execution, are planned, consistent and aiming at specific goals. The idea that public relations should not simply be a set of communication tactics, but a strategic management of different communication activities and, by doing so, contribute to the strategic management of organizations, has been discussed by Grunig and Hunt (1984), Garnett and Kouzmin (1997) and many other scholars (e.g. Koteen, 1989; Heise, 1985; Invernizzi and Romenti, 2009a; 2009b; Lee, 1999; 2001, 2007).

While intending to study how communication is practiced and managed in organizations and the contribution that public relations can provide to the strategic management of organizations, Grunig and Hunt (1984) identified four main practices, which were later named models of public relations. These four models (the press agentry/publicity, the public information; the two-way asymmetric and the two-way symmetric models) are composed of two dimensional combinations of oneway vs. two-way communication and asymmetrical vs. symmetrical communication ${ }^{1}$. In further studies, Grunig and White (1992) argued that for public relations to be excellent, it must be "symmetrical, idealistic and critical and managerial" (ibid, 307). Grunig and Hunt's (1984) four models of public relations, and in particular the two-way symmetrical one, have been criticized for providing a simplistic, normative presentation of how communication is managed in organizations (Pieczka, 1996; Van der Meiden, 1993).

Despite this criticism the four models of public relations have been the groundwork for further research on public relations practices around the world. Grunig et al., (2002) initiated an investigation with the intent to find out the value of public relations to organizations and society based on the social responsibility of managerial decisions and the quality of relationships with stakeholder publics. This study lasted more than 15 years and investigated 327 organizations from the USA, Canada and the UK. Through the combination of survey and qualitative research methodologies, the study revealed fourteen principles of public relations excellence, later to be consolidated into ten principles of public relations excellence: 1) involvement of public relations in strategic management; 2) empowerment of public relations in the dominant coalition or a direct reporting relationship to senior management; 3) integrated public relations function; 4) public relations is a management function separate from other functions; 5) public relations unit headed by a manager rather than a technician; 6) a two-way symmetrical model of public relations; 7) a symmetrical system of internal communication; 8) knowledge potential for the managerial role and symmetrical public relations; 9) diversity embodied in all roles; and 10) organizational context for excellence.

1 For a full description of the four models of public relations, see Grunig and Hunt, 1984. 
As for the four models, the generic principles have been criticized of suffering from cultural biases, being developed in an Anglo-Saxon context (Kent and Taylor, 2007). In reality, the excellence theory proposes specific, contextual variables, such as the political system, the media system, the level of economic development and the level of activism and culture, to explain some of the potential limitations or constraints on the applicability of these generic principles in certain countries around the world. Sriramesh and Vercic (2009), Grammer (2005), Limet al., (2005) and Rhee (2002), for example, have been using the generic principles in several studies and propose to use them as an effective instrument to compare public relations practices across nations and thus extend the still too limited body of knowledge in global public relations.

\section{Public Sector Communication}

Studies on public sector communication are still limited (Graber, 2003; Lee, 2007; Liu and Horsely, 2007; Gelders and Ihlen, 2010a; 2010b; Laursen and Valentini, 2010), despite the fact that communications about policies, initiatives and activities have an important role in democratic societies. It is believed, in fact, that informed citizens can make reasoned choices and participate in policy discussions and public decisions (Thomas, 1995). Interestingly, most of the studies (Édes, 2000; Heise, 1985; Laursen and Valentini, 2010; Lee, 1999; Mancini, 2006) on public sector communication focused on country and/or institution-based government communications and practices. These investigations show that civil servants working in information and communication often deal with: monitoring media coverage, briefing and advising political officials, managing media relations, informing the public directly, sharing information across the administration and formulating communication strategies and campaigns, and researching and assessing public opinion (Lee, 2001; 2007).

However, there are areas of research in public sector communication which have not yet been tackled, for example the extent of involvement by public communication officers in the strategic management of public sector organizations. Their participation in the strategic management of public sector organizations is quite relevant, considering the substantial changes in public management practices. In particular, since the beginning of the 1980's a new approach to managing public sector organizations has emerged. The new public management approach stands for more transparency, accountability and responsiveness of public sector organizations (Barber, 1986; King et al., 1998). It focuses on efficacy, planning and cost-saving models (Moynihan, 2003). It intends to tackle the needs of the community and citizens in a more effective manner (Koteen, 1989).

While many business practices could also be useful to the public sector management, Allison (2004) and Beckett (2000) concur that as public sector management differs in many respects from corporate management, and particularly in relation to communication, they believe that communication practices in the two 
spheres are far from being identical. Civil servants working in communication in public sector organizations have, in fact, four additional constraints compared to the private sector: a more complicated and unstable environment, additional legal and formal restrictions, more rigid procedures, and more diverse products and objectives (Gelders et al., 2007). Despite these constraints, Grunig and Jaatinen (1999) pointed out that the traditional models of public relations, that were primarily conceptualized in the private sector, are also valid for the public sector and acknowledge that, even if the public information model seems to be the most employed among public administrations in several countries, it is possible that other models, such as the twoway symmetrical model, are used in other parts of the world by the public sector.

\section{An Overview of the Role of Communication in the Italian Public Administration $^{2}$}

In Italy, information and communication activities from public sector organizations to citizens and other stakeholder groups were limited until the beginning of the 1990s, when the entire public administration initiated a process of modernization. This process was the result of political discussions about the state's public apparatus and the necessary measures to make it less bureaucratic and more effective, efficient, citizen-oriented and closer to the local community's needs. It is a process that is inspired by the principles of the new public management doctrine where great attention is paid to efficiency and transparency, and considers citizens as clients (Bozeman, 1991).

Changes in public management also led to a new understanding of the functions and roles of communication in the public sector (Sepe, 2003). Law no. 241/1990 was the first one introducing a normative on transparency for managing Italian public administration. The transparency normative indirectly recognizes the need to provide more information on public sector organizations' activities. It also ensures accountability of public administrations through information on public administrations' activities, new policies and services, but also citizens' participation through information about new proposals and discussions during the process of policy formulation (Mancini, 2006).

A follow-up legislation, which introduced a unit specialized in information and communication activities within public administrations, was approved in 1993. This unit, called Ufficio per le Relazioni con il Pubblico (URP) [Office for public relations] had and still has as a primary objective the development of communication flows between citizens and public administrations that facilitate citizens' participation in discussions about new policies. The creation of the URP in 1993 can be regarded as the first attempt towards the institutionalization of public communication in Italy. However, this actually did not happen until 2000 with law

2 This is a short summary of the development of public communication in Italy. For a more detailed account, see e.g. Rolando, 2011; 2010 and La Spina, 2009. 
no. 150/2000, which aimed at regulating information and communication activities within the Italian public administration. The law specifies that information activities have to be separated from those of a communicative nature. The former should include accurate presentations and the diffusion of facts and figures about policies, institutions and activities with the intent to abide to the transparency normative. The latter should focus on value creation, promotion, community marketing and the engagement of citizens and other stakeholders. This law introduces three main areas in which public communication takes place in public administrations: the spokesperson's office, the press office and the URP.

Public relations practitioners can work both in the spokesperson's office and in the URP, but they cannot take up a position in the press office as this is only reserved for accredited journalists (Mancini, 2006, Valentini, 2009). Spokespersons and press officers work primarily in communication with mass media, whereas URP officers have much larger and broader groups of stakeholders to communicate with. The main objectives in the URP are: providing information about the activities of the public administration, as well as its policies and actions to the citizens and other influential stakeholders; promoting new or specific public services; publicizing new activities and new structures in different public sector organizations (such as public institutions, state, regional and local agencies, etc.); researching public opinions and gathering inputs and feedbacks from citizens; mediating stakeholders' concerns to public administrations' specific units/people; marketing public administrations in the territory, i.e. promoting the local culture and identity (Rolando, 1998). Civil servants working in information and communication activities for public sector organizations in Italy are actively involved in what public relations literature would refer to as media relations, community relations, stakeholder relations, image management and promotional activities. Such variety of activities, which are highly interconnected to other administrative, executive and political functions of public administrations, would presuppose a certain level of strategic management of information and communication programmes.

To evaluate the extent of excellent public communication management practiced in Italian public administration, this study thus asked the following research questions:

RQ1: To what extent are public communication officers in the Italian public administration involved in the strategic management of the organization, and do they manage their information and communication programs strategically?

RQ2: What kinds of reporting relationships do public communication offices in the Italian public administration have with the dominant coalition and senior management?

RQ3: How effective are J. E. Grunig and Hunt's (1984) original four models (press agentry/publicity, public information, two-way asymmetrical, and two-way symmetrical) of public relations in describing information and communication activities in the Italian public administration? 


\section{Methodology}

In this study a survey research approach was used. Babbie (1992) has defined survey research as "the administration of questionnaires to a sample of respondents selected from the population" (ibid, 282). The survey was constructed according to the findings of the Excellence Project (Grunig, 1992), and the original survey questionnaire from the project (relevant to the 3 research questions) was thus used with a few changes. The choice for using a research instrument similar to those used in other international studies was influenced by the overarching scope of providing a comparable evaluation. This was considered imperative in order to offer an empirical basis to identify robust performance goals and to help assess the strategic role of communication in public sector organizations in different national contexts and settings.

Since the goal of this study is to understand to what extent public communication officers in Italy are involved in the strategic management of public administrations and to what extent they manage their information and communication programs strategically, only the generic principles related to the involvement of public relations in strategic management, the empowerment of public relations in the dominant coalition or a direct reporting relationship to senior management, the twoway symmetrical model of public relations, and knowledge potential for the managerial role and symmetrical public relations were tested. Since the two-way symmetrical model of public relations and symmetrical public relations are included in the four models of public relations, these were also investigated. Grunig and Hunt's models (1984) comprise the backbone of the Excellence Theory (Rhee, 2002) and can provide some insights into the extent to which public communicators in Italy are practicing symmetrical and asymmetrical activities.

\subsection{Data sampling}

The population comprises civil servants working in information and communication activities for Italian public administrations in the URP, press office, spokesperson's office and as heads of information and communication units, which coordinate the activities of the three offices. Since it was not possible to determine the exact population size or the best channel to reach public communication officers, a snowball sampling method for gathering data was chosen. An invitation email asking for participation in the online survey was sent to public relations practitioners working in the public sector through the researcher's professional contacts. The invitation email was also sent via the Italian public administration's main newsletter (Urpnews), which has about 1300 members. After excluding incomplete questionnaires, the final sample size resulted in 119 respondents.

\subsection{Research instrument}

The data was collected in 2009 and 2010 through a web-based questionnaire. The questionnaire consisted of three parts. In the first part demographic questions 
about the respondent's job position in the organization, years of experience, gender and education were asked. The second part comprised 17 statements related to the four models of public relations. The third part included 16 statements related to the involvement of public communication officers in the strategic management of public administration and information and communication programmes and their empowerment. The items measuring the four models of public relations and the selected generic principles were translated from English to Italian and re-translated from Italian to English by a second researcher who was not involved in the project to check for consistency and general understanding.

A Likert-type scale was used for the web-based questionnaire. Respondents had the possibility of choosing between different statements ranging from 1 (completely disagree) to 5 (completely agree). Respondents who did not know or did not want to respond could choose 0 . Surveymonkey.com was used as a platform for the webbased questionnaire. It was chosen because of the possibility to integrate Likert-type scale responses, its capacity for question skip patterns, graphics, animation, and even links to other pages and due to its easy interface which can significantly reduce the amount of time devoted to data entry. Web-based questionnaires have been used in other studies with positive results (Grunig and Hon, 1999; Young and Ross, 2000).

The data were analysed using the Statistical Package program for the Social Sciences (SPSS) 18 for Windows. A variable name for each statement was assigned. Descriptive statistics such as mean scores, standard deviations and Pearson correlation test were examined for all statements investigating the extent to which public communication officers in Italy are involved in the strategic management of public administrations and manage their information and communication programs strategically.

\section{Findings}

\subsection{The Italian public communication officers}

The study's participants were not equally divided; $62 \%$ were men and $38 \%$ were women. Because of the lack of information on the exact number of public communication officers working for the Italian public administration was unknown, thus the degree of confidence in this sample in terms of representativeness cannot be evaluated. Therefore, it is not possible to make any conclusion about gender distribution among public communication officers.

The participants work in URPs $(51 \%)$, press offices $(30 \%)$, spokesperson's offices $(1 \%)$ and as heads of information and communication units $(18 \%)$. Because of the limited number of valid answers from respondents working in the spokesperson's offices, this category was not further considered in the analysis. Two out of three participants are well experienced public communication officers with more than 10 years of practice (see figure 1). Participants displayed different levels 
of education, the majority having a bachelor's degree, a master's degree or a postgraduate professional certification in communication and/or public relations (figure 1).

Fig. 1. Years of work experience and educational degrees of respondents in percentage (\%)

Years of experience

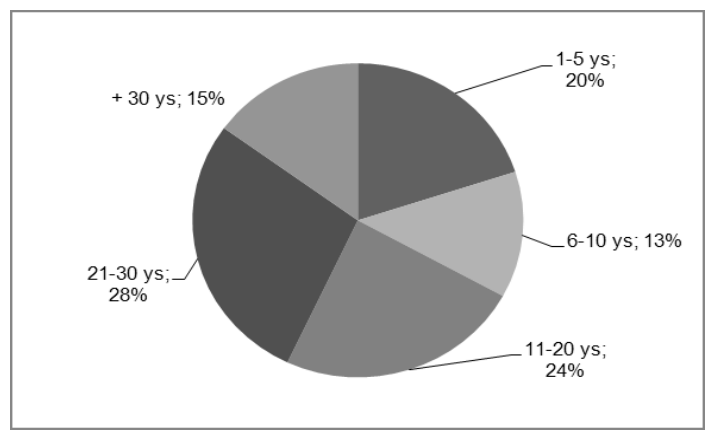

Educational degree in \%

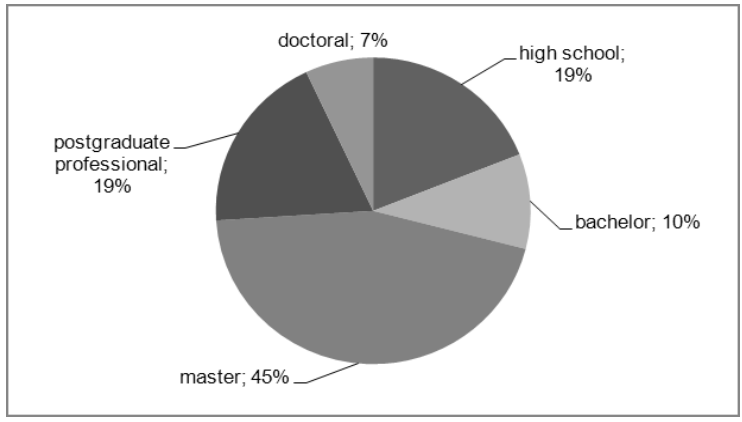

Source: own elaboration

Participants hold a variety of degrees (figure 2); the three most frequent ones are communication science (25\%), political science $(16 \%)$, and public relations $(8 \%)$. Several other degrees, like physics, engineering, architecture etc. were also mentioned (12\% "others" in figure 2$)$, indicating that a certain number of public communication officers acquired their knowledge while working in the field and not through their education. It is important to note that the majority of respondents, $59 \%$, belong to the over-40-year-old age group and since communication science and public relations degrees are relatively new educational programs in Italy, they were not available during the period in which many of the respondents attended university. 
Fig. 2: Degree majors of respondents in percentage (\%)

Degree major in \%

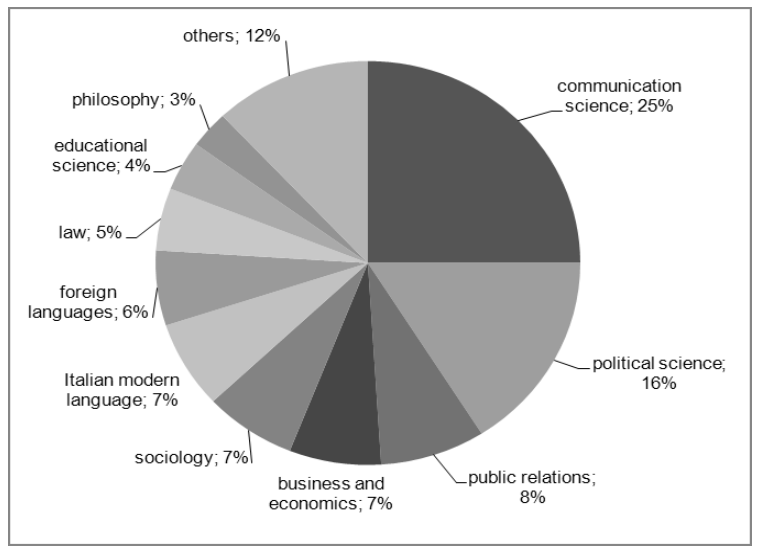

Source: own elaboration

\subsection{Communication activities in the public sector}

When asked to indicate the levels of agreement/disagreement to statements describing their communication activities in the public sector according to Grunig and Hunt's models of public relations, respondents had very different ideas about what they are actually doing. None of the four models is prevalent in the Italian public administration and all show a certain level of disagreement, i.e. all models have a mean below the neutral score 3 (see Table 1). Furthermore, the high level of standard deviation shows that answers are not evenly distributed, which would explain why no model was prevalent. Looking at the means and standard division results from each model, we can see that press agentry/publicity $(\mathrm{M}=2.94, \mathrm{SD}=$ $1.37)$ and two-way symmetrical communication $(\mathrm{M}=2.94, \mathrm{SD}=1.26)$ score very similarly. These, however, are rather opposite both in terms of communication direction and symmetry. Furthermore, the public information model which other studies (cf. Grunig and Jaatinen, 1999) indicate as the preferred approach in public sector organizations score quite low, as if public information is not the primary task of public communication officers working in Italian public administrations. This result is somehow validated when respondents express a neutral position on whether communication and public relations activities in their public administration are primarily about providing neutral information to the public. There is also a general agreement that communication, public relations and publicity are different communication activities in the Italian public administration, and this shared understanding among respondents of the three groups can arguably be a consequence of the specific Italian law separating information from communication based activities. 
Tab. 1: Level of agreement/disagreement by means and standard deviation of public relations' models in Italian public administrations

\begin{tabular}{|c|c|c|}
\hline Indicators & Mean & $\begin{array}{l}\text { Stand. } \\
\text { Dev. }\end{array}$ \\
\hline Press Agentry & 2.94 & 1.37 \\
\hline $\begin{array}{l}\text { The main purpose of my organization's communication/PR activities is to publicize } \\
\text { my organization/client. }\end{array}$ & 2.44 & 1.40 \\
\hline $\begin{array}{l}\text { In our communication/PR activities, we mostly attempt to get favourable publicity } \\
\text { into the media and to keep unfavourable publicity out. }\end{array}$ & 3.35 & 1.32 \\
\hline $\begin{array}{l}\text { We determine how successful a program is from the number of people who attend } \\
\text { an event or use our products/services. }\end{array}$ & 3.43 & 1.21 \\
\hline $\begin{array}{l}\text { In my organization, communication, public relations and publicity essentially mean } \\
\text { the same thing. }\end{array}$ & 2.53 & 1.55 \\
\hline Public Information & 2.64 & 1.26 \\
\hline $\begin{array}{l}\text { In communication/PR activities, nearly everyone is so busy writing news stories or } \\
\text { producing publications that there is no time to do research. }\end{array}$ & 2.53 & 1.42 \\
\hline $\begin{array}{l}\text { In communication/PR activities, we disseminate accurate information but do not } \\
\text { volunteer unfavourable information. }\end{array}$ & 2.99 & 1.18 \\
\hline $\begin{array}{l}\text { Keeping a clipping file is about the only way we have to determine the success of a } \\
\text { communication/PR program. }\end{array}$ & 2.08 & 1.13 \\
\hline $\begin{array}{l}\text { In my organization, communication/PR is more of a neutral disseminator of } \\
\text { information rather than an advocate for the organization. }\end{array}$ & 2.98 & 1.31 \\
\hline Two-way asymmetrical & 2.66 & 1.30 \\
\hline $\begin{array}{l}\text { After completing a communication/PR program, we do research to determine how } \\
\text { effective the program has been in changing stakeholders' opinions. }\end{array}$ & 2.30 & 1.18 \\
\hline $\begin{array}{l}\text { In communication/PR activities, our broad goal is to persuade opinion leaders } \\
\text { and/or stakeholders to have a favourable attitude towards our organization. }\end{array}$ & 2.81 & 1.24 \\
\hline $\begin{array}{l}\text { Before starting a communication/PR program, we do research to verify whether } \\
\text { our organization's goals are coherent with the stakeholders' opinions. }\end{array}$ & 2.68 & 1.44 \\
\hline $\begin{array}{l}\text { Before starting a communication/PR program, we do research to determine } \\
\text { message contents that can be easily understood and/or shared by our publics. }\end{array}$ & 2.87 & 1.35 \\
\hline Two-way symmetrical & 2.94 & 1.26 \\
\hline $\begin{array}{l}\text { Before starting a communication/PR program, we do surveys or informal research } \\
\text { to find out how much management and stakeholders understand each other. }\end{array}$ & 2.61 & 1.32 \\
\hline $\begin{array}{l}\text { The purpose of communication/PR activities is just as much to change the } \\
\text { attitudes and behaviour of management as it is to change the attitudes and } \\
\text { behaviour of opinion leaders and stakeholders. }\end{array}$ & 2.49 & 1.34 \\
\hline $\begin{array}{l}\text { The purpose of communication/PR activities is to develop a mutual understanding } \\
\text { between management and stakeholders. }\end{array}$ & 3.71 & 1.20 \\
\hline $\begin{array}{l}\text { Our organization believes that communication/PR activities should help } \\
\text { management and stakeholders negotiate conflicts and solve tensions. }\end{array}$ & 3.04 & 1.15 \\
\hline $\begin{array}{l}\text { In my organization, communication/PR activities primarily address mediation } \\
\text { between management and its different stakeholders and opinion leaders. }\end{array}$ & 2.85 & 1.32 \\
\hline
\end{tabular}

Note: All items are measured on a 5-point scale ranging from 1 to 5 , namely 1 (strongly disagree), 2 (disagree), 3 (neutral), 4 (agree), 5 (strongly agree).

Source: own elaboration 
In order to find out if years of experience had an impact on how public communication officers practice public relations, a Pearson correlation test was conducted for all four models. No significant statistical correlation was found between years of experience and public relations' models. Only some differences in means are noticeable in the press agentry/publicity model and in the symmetrical communication model.

The level of agreement towards the press agentry/publicity model increases with the years of experience (from $\mathrm{M}=2.62, \mathrm{SD}=1.37$ with $1-5$ years of experience to $\mathrm{M}=3.56, \mathrm{SD}=1.43$ with more than 30 years of experience), but the difference is not statistically significant. Similarly, for statements related to the two-way symmetrical model, those who had more than 30 years of professional work experience agreed in larger measure to practice this model followed by those in an entry level (more than 30 years: $\mathrm{M}=3.64, \mathrm{SD}=0.88 ; 1-5$ years: $\mathrm{M}=3.14, \mathrm{SD}=1.28)$, but the correlation with years of experience is not statistically strong.

The Pearson correlation test was also conducted between job position and public relations' models. Only two statements correlate in a statistically significant manner. A relationship of 0.300 (at a 0.05 level of significance) exists between job position and the asymmetrical practice of persuading opinion leaders and/or stakeholders to have a favourable attitude towards the organization. A relationship of 0.248 (at a 0.05 level of significance) exists between job position and the symmetrical practice of developing mutual understanding between management and stakeholders.

No substantial difference in means was seen when responses were grouped according to job position. The press agentry model is less used by public communication officers working in the URP than by those working in the press office or by those who are responsible for the information and communication unit (press office: $\mathrm{M}=3.03, \mathrm{SD}=1.43$; URP: $\mathrm{M}=2.82, \mathrm{SD}=1.34$; head of unit: $\mathrm{M}=3.06$, $\mathrm{SD}=1.37)$

This result is rather peculiar as it implies that press officers use persuasion more often than information in their communication activities.

Very small differences in means can also be seen in practicing two-way symmetrical communications. Respondents working in the URP or responsible for the information and communication unit agree more on this practice than the press office people (press office: $\mathrm{M}=2.59, \mathrm{SD}=1.22$; URP: $\mathrm{M}=3.06, \mathrm{SD}=1.33$; head of unit: $\mathrm{M}=3.14, \mathrm{SD}=1.11$ ). This is clearly in line with their institutional functions of building and maintaining relationships with citizens and other influential key stakeholders.

\subsection{Strategic management in the public sector}

The data reveal that most public communication officers in the Italian public administration do not contribute to the strategic management of public administration and manage information and communication programs strategically to a limited degree (see Table 2).

They mostly contribute to routine operations $(\mathrm{M}=4.06, \mathrm{SD}=1.044)$ and to formal research like press clipping $(\mathrm{M}=3.53, \mathrm{SD}=1.305)$. They tend to report their 
activities directly to the senior manager of their department/unit $(\mathrm{M}=3.83 ; \mathrm{SD}=$ $1.416)$ or directly to the $\mathrm{CEO}(\mathrm{M}=3.54 ; \mathrm{SD}=1.479)$ which in public administrations is often the Secretary General or General Manager.

They believe that they have a certain level of support in their communication activities by the senior management $(\mathrm{M}=3.27 ; \mathrm{SD}=1.25)$ but they do not think that the senior management seek their opinion $(\mathrm{M}=2.83 ; \mathrm{SD}=1.299)$ or value their judgments $(\mathrm{M}=2.91 ; \mathrm{SD}=1.312)$ when making decisions. Despite this operational role, public communication officers think they can somehow contribute to the development of goals and objectives in organizational missions and policies $(\mathrm{M}=$ 3.25 ; $\mathrm{SD}=1.371)$ and to the scanning of the environment $(\mathrm{M}=3.10, \mathrm{SD}=1.31)$.

Taking into consideration their years of experience, the group of respondents with more than 30 years of experience believe that they are involved in the strategic management to a higher degree and they consider themselves members of the senior management $(M=3.45 ; \mathrm{SD}=1.51)$. Specifically, they agree that they participate in strategic planning $(\mathrm{M}=3.92 ; \mathrm{SD}=1.44)$, help the management to develop goals and objectives $(\mathrm{M}=4.08 ; \mathrm{SD}=1.32)$, to identify both internal and external stakeholders and opinion leaders that affect the organizational mission and goals $(\mathrm{M}=3.77 ; \mathrm{SD}=$ $1.54)$, and have contacts with opinion leaders outside the public administration $(\mathrm{M}=$ 3.73; $\mathrm{SD}=1.62$ ).

The Pearson correlation test shows a significant relationship of 0.268 (at the 0.05 significance level) between years of experience and the contribution of strategic planning, and a significant relationship of 0.238 (at the 0.01 significance level) between years of experience and being a member of the senior management. These correlations indicate that the more experienced public communication officers are, the more likely they are to participate in strategic planning and be involved in the strategic management of public administrations.

Similarly as for the years of experience, public communication officers working in the position of heads of information and communication units agreed that their activities in the public administration more often aim at the strategic management than those working in the press offices or URP offices.

Higher scores are visible in their involvement in the strategic planning (head of unit: $\mathrm{M}=3.81 ; \mathrm{SD}=1.01$, press office: $\mathrm{M}=2.83 ; \mathrm{SD}=1.42$; $\mathrm{URP}: \mathrm{M}=3.02 ; \mathrm{SD}=$ 1.32 ), in helping the management to develop goals and objectives in organizational missions and policies (head of unit: $\mathrm{M}=3.78 ; \mathrm{SD}=1.17$; press office: $\mathrm{M}=3.14 ; \mathrm{SD}=$ 1.46; URP: $\mathrm{M}=3.07$; $\mathrm{SD}=1.35$ ), in identifying both internal and external stakeholders and opinion leaders (head of unit: $\mathrm{M}=3.89 ; \mathrm{SD}=1.10$; press office: $\mathrm{M}=$ 3.28; $\mathrm{SD}=1.31$; URP: $\mathrm{M}=2.79 ; \mathrm{SD}=1.34$ ).

They also believe that the senior management values their judgments in decision making (head of unit: $\mathrm{M}=4 ; \mathrm{SD}=0.73$; press office: $\mathrm{M}=2.68 ; \mathrm{SD}=1.22$; URP: $\mathrm{M}=$ $2.67 ; \mathrm{SD}=1.35)$ and that is probably why they consider themselves members of the senior management (head of unit: $\mathrm{M}=3.76 ; \mathrm{SD}=1.15$; press office: $\mathrm{M}=2.29$; $\mathrm{SD}=$ 1.41; URP: $\mathrm{M}=2.91 ; \mathrm{SD}=1.36$ ). 
Tab. 2: Level of agreement/disagreement by means and standard deviation of public communication officers' involvement in the strategic management and empowerment

\begin{tabular}{|c|c|c|}
\hline Indicators & Mean & $\begin{array}{l}\text { Stand. } \\
\text { Dev. }\end{array}$ \\
\hline \multicolumn{3}{|l|}{ Involvement in strategic management } \\
\hline $\begin{array}{l}\text { l contribute (with the dominant coalition) to the strategic planning of my } \\
\text { organization. }\end{array}$ & 3.12 & 1.33 \\
\hline $\begin{array}{l}\text { I contribute by responding to major social issues (e.g. crisis, layoffs, etc.) affecting } \\
\text { my organization. }\end{array}$ & 2.15 & 1.32 \\
\hline $\begin{array}{l}\text { I contribute to major initiatives (e.g. mergers, acquisitions, new movements in } \\
\text { markets, launch of new products/services etc.). }\end{array}$ & 2.84 & 1.43 \\
\hline $\begin{array}{l}\text { I contribute to routine operations (e.g. development and maintenance of employee } \\
\text { communication, community relations or media relations programs). }\end{array}$ & 4.06 & 1.04 \\
\hline $\begin{array}{l}\text { I conduct formal research (e.g. from news clippings, internet) for use in decision } \\
\text { making. }\end{array}$ & 3.53 & 1.31 \\
\hline I conduct informal research (e.g. informal interviews) for use in decision making. & 3.08 & 1.33 \\
\hline $\begin{array}{l}\text { I help our management develop goals and objectives in organizational missions } \\
\text { and policies. }\end{array}$ & 3.25 & 1.37 \\
\hline $\begin{array}{l}\text { I help our management scan the environment and identify issues that may be } \\
\text { potential threats or opportunities. }\end{array}$ & 3.10 & 1.31 \\
\hline $\begin{array}{l}\text { I help our management identify both internal and external stakeholders and } \\
\text { opinion leaders that affect organizational mission and goals. }\end{array}$ & 3.22 & 1.34 \\
\hline $\begin{array}{l}\text { I am in contact with opinion leaders (e.g. analysts, economists, industry experts, } \\
\text { government officials) outside the organization. }\end{array}$ & 3.18 & 1.39 \\
\hline $\begin{array}{l}\text { The senior management/dominant coalition seeks my opinion in decision making } \\
\text { or planning. }\end{array}$ & 2.83 & 1.30 \\
\hline $\begin{array}{l}\text { The senior management/dominant coalition values my judgment in decision } \\
\text { making. }\end{array}$ & 2.91 & 1.31 \\
\hline $\begin{array}{l}\text { The senior management/dominant coalition supports my communication/PR } \\
\text { decisions and activities. }\end{array}$ & 3.27 & 1.25 \\
\hline \multicolumn{3}{|l|}{ Empowerment of PR } \\
\hline I consider myself a member of the senior management/dominant coalition. & 2.88 & 1.42 \\
\hline I report my activities directly to the CEO and/or the owner of the organization. & 3.54 & 1.48 \\
\hline I report my activities directly to the senior manager of my department/unit. & 3.83 & 1.42 \\
\hline
\end{tabular}

Note: All items are measured on a 5-point scale ranging from 1 to 5 , namely 1 (strongly disagree), 2 (disagree), 3 (neutral), 4 (agree), 5 (strongly agree)

Source: own elaboration

The Pearson correlation test reveals a significant relationship of 0.306 (at the 0.01 significance level) between job position and the senior management's valuing public communication officers' judgments in decision making and a significant relationship of 0.389 (at the 0.01 significance level) between job position and being a member of the senior management. A strong relationship of 0.785 (significant at the 0.01 level) is also visible between the contribution of strategic planning and the senior management's valuing public communication officers' judgments in decision 
making. Similarly, a relationship of 0.545 (significant at the 0.01 level) exists between the contribution of strategic planning and the support by the senior management in communication activities. These correlations suggest that public communication officers in senior positions are involved in the strategic management of public administration and that the senior management supports and values their information and communication activities.

\section{Discussion and Conclusions}

The aim of this study was to discover to what extent public communication officers are involved in the strategic management of public administrations and strategically managed information and communication programs by applying four of the generic principles proposed by Vercic et al., (1996). Three questions were asked and, as the findings clearly show, public communication practices are very different.

RQ1: To what extent are public communication officers in the Italian public administration involved in the strategic management of public administrations, and do they manage their information and communication programs strategically?

The majority of public communication officers are not involved in the strategic management of public administrations but rather contribute to operational activities, such as development and maintenance of internal communication, public information, or media relations programs, as well as formal research like press clipping. This shows a low knowledge potential for the managerial role since public communication officers agree more with statements describing technical/operational activities rather than strategic ones.

It should be noted that half of the respondents work in URP offices, which handle front and back office communication activities but not public information and media relations. The fact that public communication officers outside the press offices agree to also perform public information or media relations activities indicates that the distinction between information and communication activities introduced with law no. 150/2000 and the subsequent division of functions and roles between press units and URP units is more normative than descriptive. As a previous study conducted in 2004 on the situation and trends of public communication in Italy shows, most local public administrations follow organizational models that are quite complex, more integrated and have diverse units dedicated to information and communication than those proposed by law no. 150/2000 (Rolando, 2004).

Despite the majority of respondents being in charge of operational activities, the findings also show that some of them believe that they contribute to strategic planning, help the management identify goals and objectives in the organization's mission and help them identify internal and external stakeholders. This indicates that 
at least some public communication officers are strategically managing information and communication programs. This can be considered a tepid but positive improvement from what was reported in the study conducted in 2004. In that study, results show a lack of strategic planning and reflections on implications of communication programs (Rolando, 2004). Public communication officers working as heads of the units are clearly among the respondents who are the most involved in the strategic management of public administrations.

RQ2: What kinds of a reporting relationship do public communication officers in the Italian public administration have with the dominant coalition and senior management?

The findings show that most public communication officers tend to report directly to the senior manager of their department/unit or to the Secretary General or General Manager of the local public administration. This indicates a direct relationship with the senior management and thus some knowledge potential for the managerial role. There is clearly an improvement from a 2004 study (Rolando, 2004), which reported that in one out of three local public administrations civil servants perceived communication as a staff function, and consequently communication reporting was at the unit level and not at the senior management or the dominant coalition level.

Yet, public communication officers, at the exclusion of the heads of the units, do not believe that they are members of the senior management. In particular, public communication officers working in the press office are the least likely to consider themselves as members of the senior management. This is not a surprise since press officers, among the three main information and communication functions of the Italian public administration, are primarily in charge of transmitting information on local public administration's activities and decisions to the media. Their institutional function is to achieve media coverage of the contents decided by the senior management and political actors of the local public administration, which is by its nature very operational and in line with other international studies on government communications (cf. Heise, 1985; Lee, 2001; 2007).

When years of experience and job positions are considered, some differences emerge. Senior public communication officers who coordinate and manage the information and communication units of public administrations tend to agree more often with the statement indicating their membership of the senior management and their belief in the fact that the senior management value and support information and communication activities that are developed by their units. All in all, this result indicates that while most public communication activities in the Italian public administration are operational, some are strategic and genuinely taken into consideration in the public management of local public administrations. 
RQ3: How effective are J. E. Grunig and Hunt's (1984) original four models (press agentry/publicity, public information, two-way asymmetrical, and two-way symmetrical) of public relations in describing information and communication activities in the Italian public administration?

The findings show that no public relations model is prevalent in the information and communication activities of the Italian public administration, indicating that public communication officers employ only certain aspects of each of the four models. Thus, the claim that the public information model is the most widely used model in public sector organizations cannot be confirmed by this study (Grunig and Jaatinen, 1999; Lim et al., 2005). Interestingly, the press agentry/publicity model and the two-way symmetrical model are the models that received the least disagreement among the four models. Pearson correlation tests were calculated to check for relationships between years of experience and choice of answers, as well as between job positions and choice of answers, but no significant statistical result was found. This leads to the conclusion that public communication officers working in press offices, URPs and as heads of units use a mixed model of publicity, information, asymmetric and symmetric activities with different purposes. A mixed model, in fact, seems to best represent the work of public communication officers in the Italian public administration. These civil servants are simultaneously involved in processes and activities whose aims are nourishing relationships and listening to stakeholders, informing and responding, managing and organizing (Fiorentini, 1995; Mancini, 2006; Rolando, 1998).

Finally, statements measuring the extent to which public communication officers do research to verify the clarity of message or coherence between the organization's goals and stakeholders' opinion and conduct surveys to determine how effective the program was, all scored very low. These results indicate that research and measurement, apart from press clipping, is still scarce in public administrations' communication activities.

This study offers some new insights into the strategic management of public administrations and information and communication programs by public communication officers in Italy. It contributes to the existing knowledge on public relations and public communication by offering a specific analysis of the strategic management of information and communication programs in the Italian public administration. This study shows that while information and communication activities and roles in local public administrations are similar to those performed by other public sector organizations across western countries, there are peculiarities in the way communication is perceived and conducted which are specific to the investigated country. Specifically, the findings pinpoint that the affiliation to a specific unit or educational background of public communication officers does not affect the way they perform information and communication activities across the four models of public relations. The findings also question the validity of the four models of public relations which seem not to capture completely the complexity of 
$21^{\text {st }}$ century communication in organizations. Furthermore, at a practical level, the results implicitly show the weakness of the Italian organizational models proposed by law no. 150/2000, which separates information from communication functions. Such distinction seems not to resonate with the practices of Italian public communication and rather to be an obstacle for integrating internal and external communication in a strategic manner. Because of the great complexity of handling multiple stakeholders and greater constraints in public sector organizations in terms of resources and qualified personnel, information and communication activities of the Italian public administration should move towards more integrated organizational models. Here communication is a "transversal activity" across different public management functions and contributes to the public administration's governance (Invernizzi and Romenti, 2009b; La Spina, 2009; Rolando, 2010).

Further research is needed to better understand the particular dynamics of public relations in public sector organizations. Future investigations should link public relations in the information and communication activities of Italian public administrations to specific environmental factors such as culture, economic system, political structure, level of development, media system and the extent of activism which are found to be useful variables in explaining international public relations practices (Lim et al., 2005; Kent and Taylor, 2007). Likewise, they should look more closely at dimensions measuring the 'publicity' construct in public administrations as 'publicity' about public services, promotion of culture, local events and territory may have different communication directions and symmetry for public communication officers.

The study holds some limitations in terms of generalizability. Since there is no public record identifying the exact number of public communication officers and respondents working in spokespersons' offices were underrepresented in this study, it is not possible to draw inferences or general conclusions from the findings. The study has some limits related to the chosen quantitative research approach, which provides less elaborate accounts of public communication officers' perceptions of the strategic role of communication in the public sector than qualitative ones.

\section{References}

ALLISON G.T. (2004), "Public and private management: Are they fundamentally alike in all unimportant aspects?", in Shafritz J.M., Hyde A.C., Parkes S.J. (Eds.), Classics of public administration, Wadsworth, Belmont, CA.

BABBIE E. (1992), The practice of social research (6 ${ }^{\text {th }}$ ed.), Wadsworth, Belmont, CA.

BARBER B. (1986), Strong democracy: Participatory politics for a new age, University of California Press, Berkeley, CA.

BECKETT R. (2000), "The 'government should run like a business' mantra", American Review of Public Administration, vol. 30, n. 2, pp. 185-204.

BOZEMAN B. (1991), Public Management - The State of the Art, Jossey-Bass, San Francisco, CA

DUCCI G. (2007), Pubblica amministrazione e cittadini: una relazionalità consapevole : gli sviluppi di una comunicazione pubblica integrate, Franco Angeli, Milano. 
ÉDES B.W. (2000), "The role of government information officers", Journal of Government Information, vol. 27, n. 4, pp. 455-469.

FAIRBANKS J., PLOWMAN K.D., RAWLINS B.L. (2007), "Transparency in government communication", Journal of Public Affairs, vol. 7, n. 1, pp. 23-37.

FIORENTINI G. (1995), Il marketing dello Stato, Editrice Bibliografica, Milano.

GARNETT J.L., KOUZMIN A. (1997), Handbook of administrative communication, Marcel Dekker, New York.

GELDERS D., IHLEN Ø. (2010a), “Government communication about potential policies: Public relations, propaganda or both?", Public Relations Review, vol. 36, n. 1, pp. 5962.

GELDERS D., IHLEN Ø. (2010b), "Mapping the gap: applying a service marketing model into government policy communications", Government Communication Quarterly, vol. 27, n. 1, pp. 34-40.

GELDERS D., BOUKAERT G., VAN RULER B. (2007), "Communication management in the public sector: consequences for public communication about policy intentions", Government Information Quarterly, vol. 24, n. 2, pp. 326-337.

GRABER D.A. (2003), The power of Communication. Managing Information in Public Organizations, CQPress, Washington D.C.

GRAMMER E.M. (2005), An exploration of the generic principles of public relations excellence in Australia, Italy, Mauritius, and Uganda, Unpublished master thesis, University of Maryland, USA.

GRUNIG J.E. (1992), Excellence in public relations and communication management, Lawrence Erlbaum Associates, Hillsdale, NJ.

GRUNIG L.A., GRUNIG J.E., DOZIER D.M. (2002), Excellent public relations and effective organizations: A study of communication management in three countries, Lawrence Erlbaum, Mahwah, NJ

GRUNIG J.E., HON L.C. (1999), Guidelines for measuring relationships in public relations, The Institute for Public Relations, Gainesville, FL.

GRUNIG J.E., HUNT T. (1984), Managing public relations, Harcourt Brace Jovanovich, New York.

GRUNIG J.E., JAATINEN M. (1999), "Strategic, symmetrical public relations in government: From pluralism to societal corporatism", Journal of Communication Management, vol. 3, n. 3, pp. 218-234.

GRUNIG J. E., WHITE J. (1992), “The Effect of Worldviews on Public Relations Theory and Practice", in Grunig J. (Ed.), Excellence in public relations and communications management, Lawrence Erlbaum Associates, Hillsdale, NJ.

HEISE J.A. (1985), "Toward closing the confidence gap: An alternative approach to communication between public and government", Public Administration Quarterly, vol. 9, n. 2, pp. 196-218.

INVERNIZZI E., ROMENTI S. (2009a), "Institutionalization and Evaluation of Corporate Communication in Italian Companies", International Journal of Strategic Communication, vol. 3, n. 2, pp. 116-130.

INVERNIZZI E., ROMENTI S. (2009b), Strategic communication and decision-making processes: toward the communication oriented organization, Paper presented at the EUPRERA Congress 2009 "Corporate citizens of the third millennium. Towards a Shared European Perspective", Bucharest, Romania, September 23-26, 2009.

KENT M., TAYLOR M. (2007), "Beyond Excellence: Extending the generic approach to international public relations. The case of Bosnia", Public Relations Review, vol. 33, n. 1 , pp. 10-20. 
KING C.S., FELTEY K. M., O’NEIL SUSEL B. (1998), “The question of participation: Toward authentic public participation in public administration", Public Administration Review, vol. 58, n. 4, pp. 317-325.

KOTEEN J. (1989), Strategic management in public and non-profit organizations: Thinking and acting strategically on public concerns, Praeger, New York.

LAURSEN B., VALENTINI C. (2010), "Communicating the EU to the Media: the Delicate Role of Press Officers at the EU Council of Ministers", in Vercic D., Sriramesh K. (eds.), Proceedings of the 17th International Public Relations Research Symposium Bledcom, pp. 162-170.

LA SPINA A. (2009), Comunicazione pubblica e burocrazia, Franco Angeli, Milano.

LEE M. (1999), "Reporters and Bureaucrats: Public Relations Counter-Strategies by Public Administrators in an Era of Media Disinterest in Government", Public Relations Review, vol. 25, n. 4, pp. 451-463.

LEE M. (2001), "The agency spokesperson: connecting public administration and the media", Public Administration Quarterly, vol. 25, n. 1, pp. 101-130.

LEE M. (2007), Government Public Relations: A Reader, CRC Press, Boca Raton, FL.

LIM S., GOH J., SRIRAMESH K. (2005), “Applicability of the Generic Principles of Excellent Public Relations in a Different Cultural Context: The Case Study of Singapore", Journal of Public Relations Research, vol. 17, n. 4, pp. 315-340.

LIU B., HORSLEY J. (2007), "The government communication decision wheel: Towards a public relations model for the public sector", Journal of Public Relations Research, vol. 19, n. 4, pp. 377-393.

LUOMA-AHO V., PELTOLA S. (2006), "Public Organisations in the Communication Society", Publication of the Department of Communication, University of Jyväskylä, Jyväskylä, Finland.

MANCINI P. (2006), Manuale di comunicazione pubblica, Laterza, Bari.

MOYNIHAN D.P. (2003), "Normative and Instrumental Perspectives on Public Participation. Citizen Summits in Washington D.C.", American Review of Public Administration, vol. 33, n. 2, pp.164-188.

PIECZKA M. (1996), "Paradigms, Systems Theory and Public Relations", in L'etang J., Pieczka M. (eds.), Critical Perspectives in Public Relations, International Thomson Business Press, Londra.

PRSA (2012), What is Public Relations? PRSA's Widely Accepted Definition, Public Relations Society of America, URL: http://www.prsa.org/AboutPRSA/PublicRelationsDefined, accessed on 28 February 2013

RHEE J. (2002), "Global Public Relations: A Cross-Cultural Study of the Excellence Theory in South Korea", Journal of Public Relations Research, vol. 14, n. 3, pp. 159-184.

ROLANDO S. (1995), La comunicazione pubblica in Italia, Editrice Bibliografica, Milano.

ROLANDO S. (1998), Un Paese spiegabile. La Comunicazione Pubblica negli anni del cambiamento, delle autonomie territoriali, delle reti, Etas Libri, Milano.

ROLANDO S. (2003), Teoria e tecniche della comunicazione pubblica. Dallo Stato sovraordinato alla sussidiarietà (seconda edizione), Etas Libri, Milano.

ROLANDO S. (2004) (a cura di), Situazione e tendenze della comunicazione istituzionale in Italia (2000-2004), Rapporto al Ministro per la Pubblica Funzione, Università IULM.

ROLANDO S. (2010), La comunicazione pubblica per una grande società. Ragioni e regole per un migliore dibattito pubblico, Etas Libri, Milano.

ROLANDO S. (2011), Teorie e techniche della comunicazione pubblica, Rizzoli, Milano. 
SEPE S. (2003), “Cittadini e cittadinanza”, in Rolando S. (a cura di), Teorie e tecniche della comunicazione pubblica, Etas Libri, Milano.

SRIRAMESH K., VERCIC D. (2009), The global public relations handbook. Theory, Research, and Practice ( $2^{\text {nd }}$ ed.), Routledge, New York.

THOMAS J. C. (1995), Public participation in public decisions, Jossey-Bass, San Francisco.

VALENTINI C. (2009), "Italian Public Relations in a Changing World. Historical Overview, Current Questions and Future Challenges", Prism, vol. 6, n. 2, pp. 1-11.

VALENTINI C., MUZI FALCONI T. (2008), Lo specchio infranto: Come i relatori pubblici e $i$ giornalisti italiani percepiscono la propria professione e quella dell 'altro, Luca Sossella Editore, Roma.

VAN DER MEIDEN A. (1993), "Public relations and "other" modalities of professional communication: Asymmetric presuppositions for a new theoretical discussion", International Public Relations Review, vol. 16, n. 3, pp. 8-11.

VERCIC D., GRUNIG L.A., GRUNIG J.E. (1996), "Global and specific principles of public relations: Evidence from Slovenia", in Culbertson H., Chen N. (eds.) International public relations: A comparative analysis, Lawrence Erlbaum Associates, Mahwah, NJ.

YOUNG S.J., ROSS C.M. (2000), "Web questionnaires: A glimpse of survey research in the future", Parks and Recreation, vol. 35, n. 6, pp. 30-39. 
